\title{
Past and present: cartographic history of Famagusta
}

\begin{abstract}
The island of Cyprus has been occupied by various powers, during which time the historical and cultural contexts of the main cities of the island have changed and left behind material traces. One of these cities is the main port city of the island Famagusta, where the various ruling powers affected its fabric and the different historic structures of the city combine with modern in the contemporary city. These multicultural structures and historical layers can be followed on the maps. The aim of this paper is to follow the changing urban fabric of Famagusta by examining the selected maps from the $16^{\text {th }}$ century to modern times. How much the city undergoes spatial alteration and how much of the historical structure and developments can be followed on the cartographic records? The paper will question the perspective of the cartographers towards Famagusta and their priorities in depicting this multicultural city.
\end{abstract}

Keywords

Urban cartography • Cyprus • Famagusta

(C) University of Warsaw - Faculty of Geography and Regional Studies

\author{
Merve Senem Arkan \\ Nicosia, Cyprus \\ e-mail:m.senemarkan@gmail.com \\ Received: 30 October 2018 \\ Accepted: 28 January 2019
}

Introduction

The island of Cyprus has been occupied by various powers, during which time historical and cultural contexts of the main cities of the island have changed and left behind material traces. Possessing one of the most important harbours in Cyprus, Famagusta is a port city located on the eastern coast of the island. The city has its roots in an ancient, powerful and rich city called Salamis, which once stood $7 \mathrm{~km}$ north of Famagusta and served as the capital city around 550 B.C. However, the city was destroyed by giant waves, several earthquakes and constant attacks as part of the Arab invasions, which eventually destroyed it completely in 648 A.D. (Gunnis 1947). As a result of this destruction, a new settlement, Arsinoe (Ammochostos) populated with refuges from Salamis, was built on the site where today's Famagusta stands. When Acre fell in 1291, the island and the city rapidly acquired importance (Enlart 1987), and during the $14^{\text {th }}$ century, Famagusta experienced its glory days with its population expanding to include various cultures. Its location on important trade routes meant that its government and economy were based on commerce (Uluca \& Akın 2008), which affected its urban fabric. The Muslim conquests of the Levantine coastline and with it the movement of refugees from the Frankish states of the Levant to Famagusta, also assisted its rise (Jacoby 1989). The arrival of refugees from Christian ports, particularly from Acre, comprising of different nationalities, particularly Genoese, Venetian and Pisans, caused the rise of commercial activities in Famagusta harbour (Edbury 1999). In 1373, the city was occupied by the Genoese (Gunnis 1947), who tried to maintain Famagusta as the main harbour of the island, but despite their efforts, its economic decline commenced (Marangou 2002). The Genoese invasion of the city caused great damage to its wealth, trade relations and more importantly its inhabitants. Additionally, plague affected the city, causing large numbers of deaths (Cobham 1908). In 1464, the Lusignan dynasty regained control but their period ended in 1489 with Venetians taking over the island (Gunnis 1947). In 1571 the city and the island became part of the Ottoman Empire. In 1878 the island was rented to the British Empire until it achieved its independence in 1960 when the island separated into two governments; Turkish Republic of Northern Cyprus (TRNC) in the north, and Republic of Cyprus in the south. Today the city is part of the TRNC, with a population of 40,920 in 2011

The diverse historical structures combine with the modern in the contemporary city. These multicultural structures and historical layers can be followed on the maps. J.B. Harley defines maps as an 'historical source' emphasizing that "Maps are a graphic language to be decoded. They are a construction of reality, images laden with intentions and consequences that can be studied in the societies of their time" (Harley 2001, p.36). This paper's aim is to follow the changing urban fabric of Famagusta by examining selected maps created between 1571 during the siege by the Ottoman Empire and the modern maps by TRNC. The selected maps for each era are based on the details they were given about the inner city to analyse the visual changes that the city underwent with each new ruling power. The four maps are not representative of the era's cartographic style but detailed enough to observe the changes the inner city underwent in each era. To what extent did the city alter spatially and how much of the historical structure and developments can be followed on the cartographic records? The paper will question the perspective of 
the cartographers towards Famagusta and their priorities when depicting this multicultural city.

\section{Venetian Famagusta}

The walled city underwent changes to improve its defences at the beginning of the $14^{\text {th }}$ century, with the enlargement of the inner castle, the strengthening of the fortifications and the remodelling the main squares (Edbury 1999). Later, during the Venetian era, the fortifications were further renovated to face a possible Ottoman invasion. The Ottoman Empire commenced its conquest of the island in 1570 and by October, they had already taken almost all of Cyprus' cities including the capital Nicosia, after which their attention turned to Famagusta, the last city remaining for the Ottomans' victory over Venetians to be complete. Following the invasion in 1571 , the island became a part of the Ottoman Empire. It was during these years of siege, that the city played an important role in the war between the ruling powers of the Mediterranean. So detailed maps were created to represent and identify the city in detail.

Famagusta was surrounded by roughly rectangular stone fortifications and a defensive moat, to the east of which was the harbour. The city walls and the harbour played an important role in the city's formation and identity. During the Venetian era, the government focused on the reconstruction of the fortification of the city. Today's fortification took its final shape in this era, with important additions such as the Martinengo bastion. The walls resisted the Ottoman troops for a year, so this fortification may be considered a great example of the Venetian military architecture. In addition to the walls, Famagusta's natural harbour, which determined the city's formation, economy, status, culture, society etc., is the city's second significant feature. Two towers protected the entrance, one of which was the citadel (the main defence structure of the port), and a chain was hung between them (Enlart, 1987). Little changed between the $14^{\text {th }}$ and $19^{\text {th }}$ centuries as no improvements were made to the harbour (Uluca \& Akın 2008). A good centre for trade, and a refuge for pilgrims travelling to and from Jerusalem, the harbour became a sanctuary, playing an important role during wartime. Hence, the harbour and the walls are remarkable and often emphasized in maps as the central core of the city's structure. There are two gates to the city, the Sea Gate (Porta del Mare) and the Land Gate (Porta di Limisso), the former constructed during the Venetian period (Uluca \& Akın 2008) and the main thoroughfare through Famagusta runs between the gates, along which was located its historic market (Jeffery 1918). Two important buildings are located in the piazza: the palace, and St. Nicholas Cathedral. Famagusta became one of the wealthiest cities in the region during the $14^{\text {th }}$ century under the Lusignans rule and when St. Nicholas Cathedral, the largest medieval building in Famagusta was built. There were many other Christian edifices of many denominations, such as Saints. Peter and Paul, St. George Greek (Orthodox Cathedral of Famagusta) and St. George of the Latins and many others. Some are in ruins, some are still standing and all allow us a glimpse of the changing socio-political and economic context of the city.

The first map analysed was made by Stephano Gibellino (Stylianou 1980; Arkan 2017, Fig. 1). It became one of the most important sources for the study of Venetian Famagusta and the siege. The siege is depicted on the map with the Ottoman troops and the ships outside the city, showing the line of fire between the city and the troops. More importantly, the map is the most detailed one from the $16^{\text {th }}$ century and provides detailed information about the city's structure and inner planning, which is what this paper will focus on. The map has a reference table with the names of the buildings, the bastions, and the city gates. Inside the walls, the different designs of the important public buildings are depicted on larger scale than the private buildings, which have simplified designs that form blocks within the city. For example, St. Nicholas Cathedral may be identified easily by its oval shape and its two towers. While the map is detailed, it is not entirely accurate. Gibellino drew the Saints Peter and Paul Church in the wrong position in order to show both the church and the palace (Enlart 1987). The map also provides lost information about the city as it depicts the two Venetian columns and the tomb of Venus between them, in front of the Cathedral. These structures are in different locations today. The empty area near the Othello Tower is labelled "loco di trar al palio" and was used for civic events. The map simply illustrates the important features of the city, its military architecture, civic and religious buildings, and structural elements.

\section{Ottoman Famagusta}

After the conquest of the island, significant changes occurred in the island's administration, culture, and religion. Cyprus had been a Christian island (although with various ethnic groups) before the conquest (Luke 1969) and afterwards, it was transformed into a Muslim country. Symbolically, this transformation was epitomized in Famagusta with the conversion of St. Nicholas Cathedral and Saints. Peter and Paul into mosques. Many other public buildings' functions were altered too. The Christian population was forced out of the city, to the south "where there were plenty of orchards and gardens and (where they) founded the new Famagusta: "Varosha" (Marangou 2002, p.127). So travellers could only describe what they could see from the outside as permission was not granted for Christians to enter the city. In the next century, this rule was abolished. Cyprus was still an important trade centre, but this was no longer carried out through the port of Famagusta and with the deepening lack of interest and usage of the port, its condition deteriorated and large ships were not able to use it. The abandonment of the port of Famagusta affected the condition of the city and its population. After the siege in 1571 , as the population of the city was decreased due to the war, in 1573-74, the Ottoman Empire sent people and soldiers from Turkey to increase the population of the city. But the harsh fate of the city was sealed as more problems arose including drought, plague and famine, turning the once lively city into an almost empty ruin (Cobham 1908).

With the decreased activity of the port, the road between the Land Gate to the Palace area became the main thoroughfare. On the other hand, the roads from the Palace area to the north wall (towards the Martinengo Bastion) were abandoned and eventually disappeared. The population was excessively gathered around the Palace area (Uluca \& Akın 2008). During the siege, the city was severely damaged; hence the Ottoman administration's first job was to restore these damaged structures. The siege was one reason for the slow demolition of the city, the decreasing population was the second. Houses and churches were left empty and many structures were neglected. During the process of converting the whole city, new constructions were started: the Cafer Paşa fountain and bath, which was located beside the Palace, and the Medrese (school) beside the Cathedral dominated the main square. Inside the walled city, three baths, Keltikli, Cafer Pasha and Kızıl baths were also built. The empty area at the north-east side of the city, called the "palio", was used for javelin practice during the Ottoman period. In this area, many buildings were demolished and used for agricultural purposes (Uluca \& Akın 2008). A new land gate was opened during this period, very close to the Ravelin Gate, which was later called the Akkule Gate (Torrione di Limisso) (Uluca \& Akın 2008). After the initial reconstructions, the Ottoman administration did not construct any new buildings. The restoration of the fortification was completed and other structures were not a priority (Gunnis 1947).

Olfert Dapper created maps from large numbers of travellers' accounts, and his work Description of Africa is especially well 


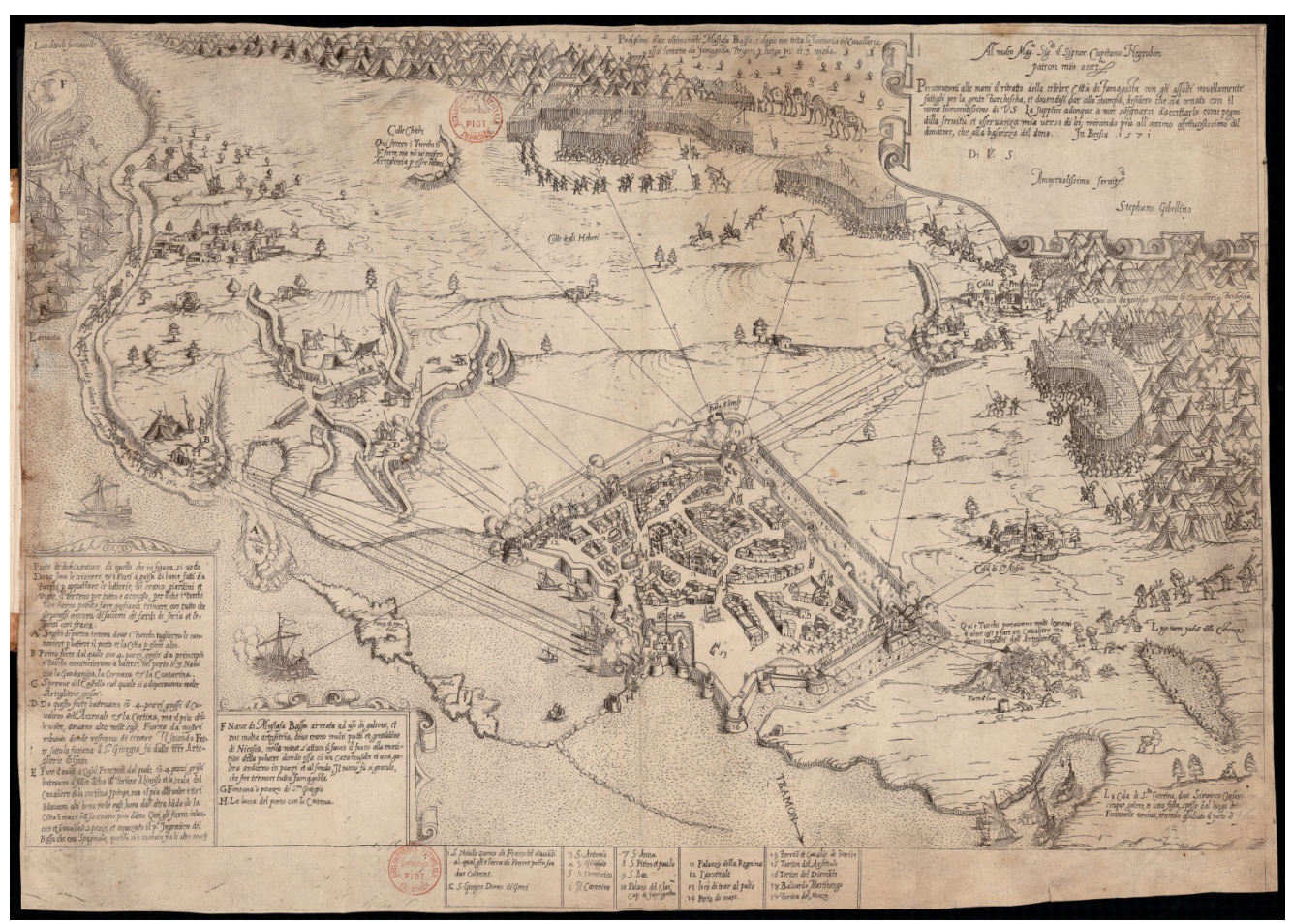

Figure 1. Stephano Gibellino, "Al motto Mag. Sig. ...Negrobon... ritratto della celebre citta di Famagosta", Brescia, 1571 (Gibellino 1571). Source: Bibliothéque Nationale, Departement des Imprimés, Paris

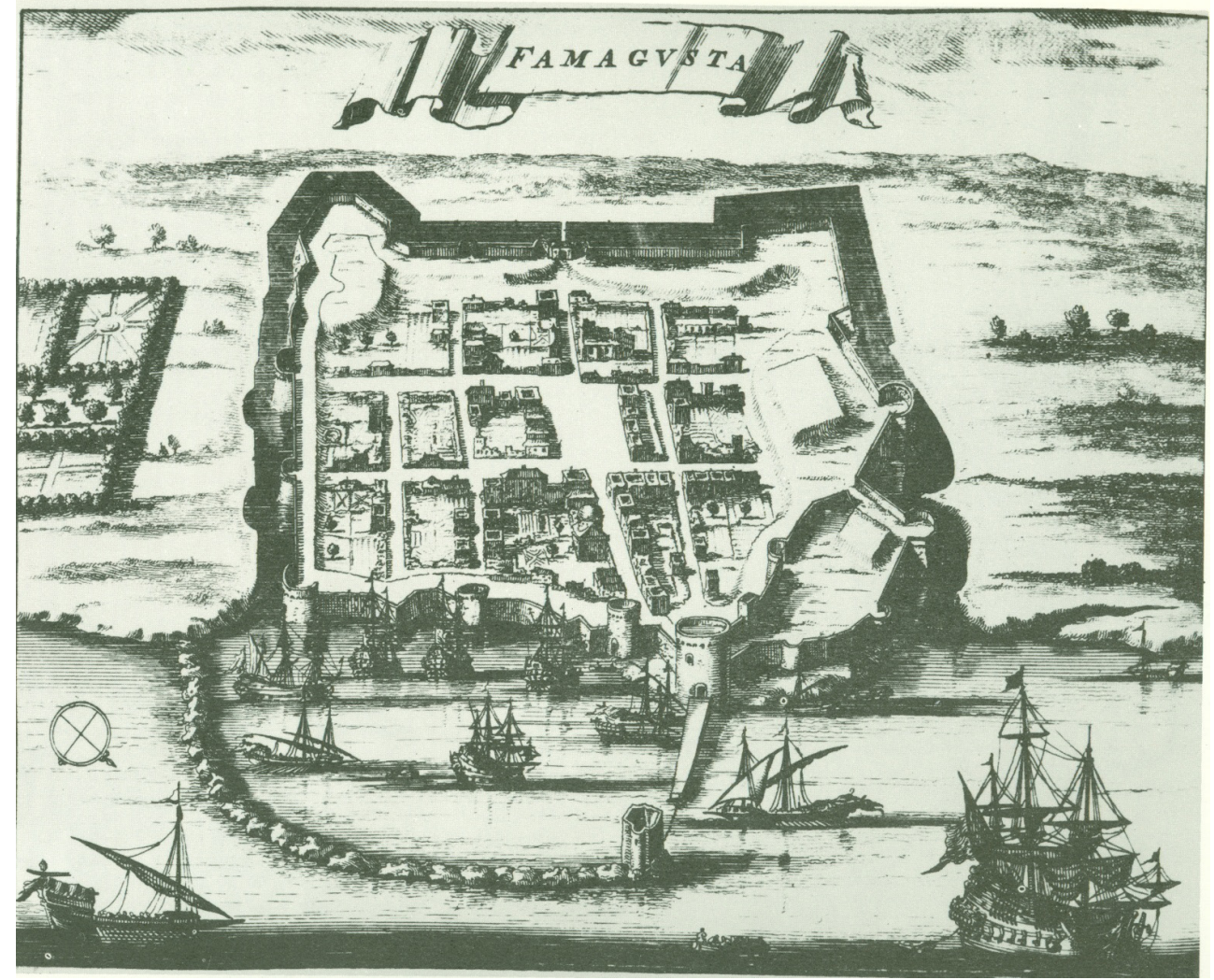

Figure 2. Olfert Dapper, "Famagusta”, Amsterdam, 1688 (Dapper 1688). Source: Hellenic Library - Alexander S. Onassis Public Benefit Foundation, Aikaterini Laskaridis Foundation 
known (Arkan 2017, Fig. 2). In his book, besides geographical information, he also included information on the economy, politics, medicine, social life and customs. This copper engraving map of Famagusta from his book Naukeurige Beschryving der Eilanden in de Archipel der Middlelantsche Zee (ed. Navari 2003) was perhaps the most interesting map of the century, as the majority of maps focused on the fortification alone. It is a bird's eye view of the city, which shows the inside of the walls, though the depiction of the citadel is inaccurate (Stylianou 1980). The map is probably based on a wooden model of the city from the $16^{\text {th }}$ century, made in Venice (ed. Navari 2003), so the fortification is almost accurately depicted but dated. The fortification was drawn as a square where it should have been a rectangle. Inside the city, he depicts blocks of buildings to represent the private buildings, gardens, and roads. Public buildings are depicted on a larger scale but there is no indication of the names of specific buildings. The road system and blocks of buildings are shown but none of the churches or the new Ottoman constructions were included (Stylianou, 1980). The city is shown as ruined buildings, however, the absence of the main buildings means the image is unreliable. Varosha is presented as fertile with gardens, which gives updated information about the outside of the city.

\section{British Famagusta}

The Ottoman Empire, which was at war with the Russian Empire, requested help from the British Empire. In return for their assistance, they rented Cyprus to the British in 1878, but as they fought on opposite sides during the First World War, the British Empire claimed the island as theirs in 1914 and made it a full colony in 1925. The British colonial rule depended on the ethnic division between the Greek majority and the Turkish minority. However, the uneasiness within the island and the conflict between the citizens and the new government continued. In 1950, with a referendum, $96 \%$ of Greek Cypriots voted for unification with Greece (Enosis) (Richter 2011). EOKA (National Organisation of Cypriot Fighters) officially started a military campaign in 1955 (Stavrinides 1999). The constant conflict and rebellion against the British government lead to negotiations and the search for a solution. As a result, the Zurich and London Agreements were signed in 1959, which led to the establishment of the Republic of Cyprus on 16 August 1960 (Stavrinides 1999).

When the British Empire took over the island, the priority was the development of the harbour, despite its poor condition (Marangou 2002). The British administration reports recorded that the harbour was silted up with sand and rocks so it could only be used for small ships (Marangou 2002). The constructions in the city can be separated into two sections. The first was between 1878 and 1930 and the second between 1930 and 1960. During the first section, renovations were focused on the North-West and North-East of the city. The majority of the construction of the harbour was done in this period. New warehouses were built close to the harbour. Existing buildings were used for various purposes. Saints Peter and Paul Church was used as a grain and potato warehouse, the Tophane bastion and St. George of Latins Church's garden was used as fuel store and the Venetian house was used as a women's prison. The remaining parts of the Palace were used as police offices, as during the Ottoman period. Some churches were reconstructed and reopened (Uluca \& Akın 2008). In order to clean the main square and highlight the Lala Mustafa Mosque, they demolished two buildings on the west side of the mosque. New laws to protect the city were passed such as the Antiquities law established in 1905, which only included monuments built prior to the Ottoman era. One exception is the reuse of the Ottoman school (mescid) as the Antiquities Department (Uluca \& Akın 2008). In addition, new gates were opened to the harbourside in order to make entry and exit easy. They were located between the Sea Gate and the Citadel, and the Sea Gate was closed completely. Probably the biggest change to the city was the addition of the railways. In 1904, 36 miles of railway were built to connect Larnaca, Nicosia and Famagusta (Orr 1972). During the second period, constructions of private buildings and shops especially between the centre to the Land gate improved the quality of the city (Uluca \& Akın 2008). The agricultural areas inside the walled city were removed. Within the walls, new buildings such as schools, a municipal market, a library and private houses were built. The British government moved the administrative centre out of the walled city to the area between the city and Varosha, where they built new government buildings, the court, a hospital, and the police headquarters.

The map was made during the survey under the command of Lieutenant S.C.N. Grant (Fig.3). It shows the inside of the walled city in detail, showing the public buildings, fields and private building complexes. It also gives names of few churches, bastions and the land gate. The Greek names of the churches were given and the converted churches are not emphasized by omitting their Turkish names. The Turkish names are only given for the bastions. The surprising thing about this map is the erroneous labelling of two important churches: St. Nicholas Cathedral is the biggest structure in the middle of the city and is labelled as "Ayia Sophia" and Saints Peter and Paul "Ayios Nikolaos". Different usage of the churches during this era is not emphasized on the map. Other than these structures, inside the walled city surprisingly only one mosque, Mustafa Pasha Mosque is shown because the name of the church was unknown by this time (Enlart 1987) and the second structure was a mansion called "konak". The yellow painted areas show houses where the by now partially demolished Venetian palace used to be. The agricultural areas are still inside the walled city showing that this is a map from the early period of the British era. The sea gate, which was replaced during this era is not represented. The private buildings are depicted as blocks without any details. Outside the city walls, there isn't much to illustrate except the Turkish cemetery and the Tekke which is a monastery for dervishes.

This map is from the early part of the British era and doesn't capture many of the changes that had occurred, neglects the historical context and contains erroneous information about the city. However there aren't any other detailed maps of the walled city, except the map of Famagusta by Karl Baedeker from his 1914 travel guide Konstantinopel, Balkanstaaten, Kleinasien, Archipel, Cypern (ed. Navari 2003). As a tourist map, it shows the religious buildings, especially the Christian monuments and doesn't give details about the modifications by the British government.

\section{Modern Famagusta}

After the establishment of the Republic of Cyprus in 1960 the conflict between the Turkish and Greek Cypriots didn't end but escalated especially between 1963 and 1974 (Richter 2011). A truce was made and Nicosia was divided by a green line of UNFICYP troops. However, on 15 July 1974, with the support of Greek junta, Greek Cypriots, staged a coup d'état to unify the island with Greece and in response, the Turkish troops landed on the island on 20 July (Richter 2011; Stavrinides 1999). The result was the delimitation between the communities due to the rapid migration of the locals and the subsequent division of the island. On 15 November 1983, the Turkish Republic of Northern Cyprus (TRNC) was declared in the north of the island but only recognized by Turkey while the Republic of Cyprus in the south continued. Famagusta became part of North Cyprus, and as an unknown port, the city never regained its popularity.

1960 to1974 was a chaotic period, the city's historical texture was ignored and several buildings were destroyed or demolished. Under the 1960s government, the municipality of the walled city belonged to the Turkish Cypriots and Greek Cypriots for other districts (Önal, et al. 1999). After the war, the 


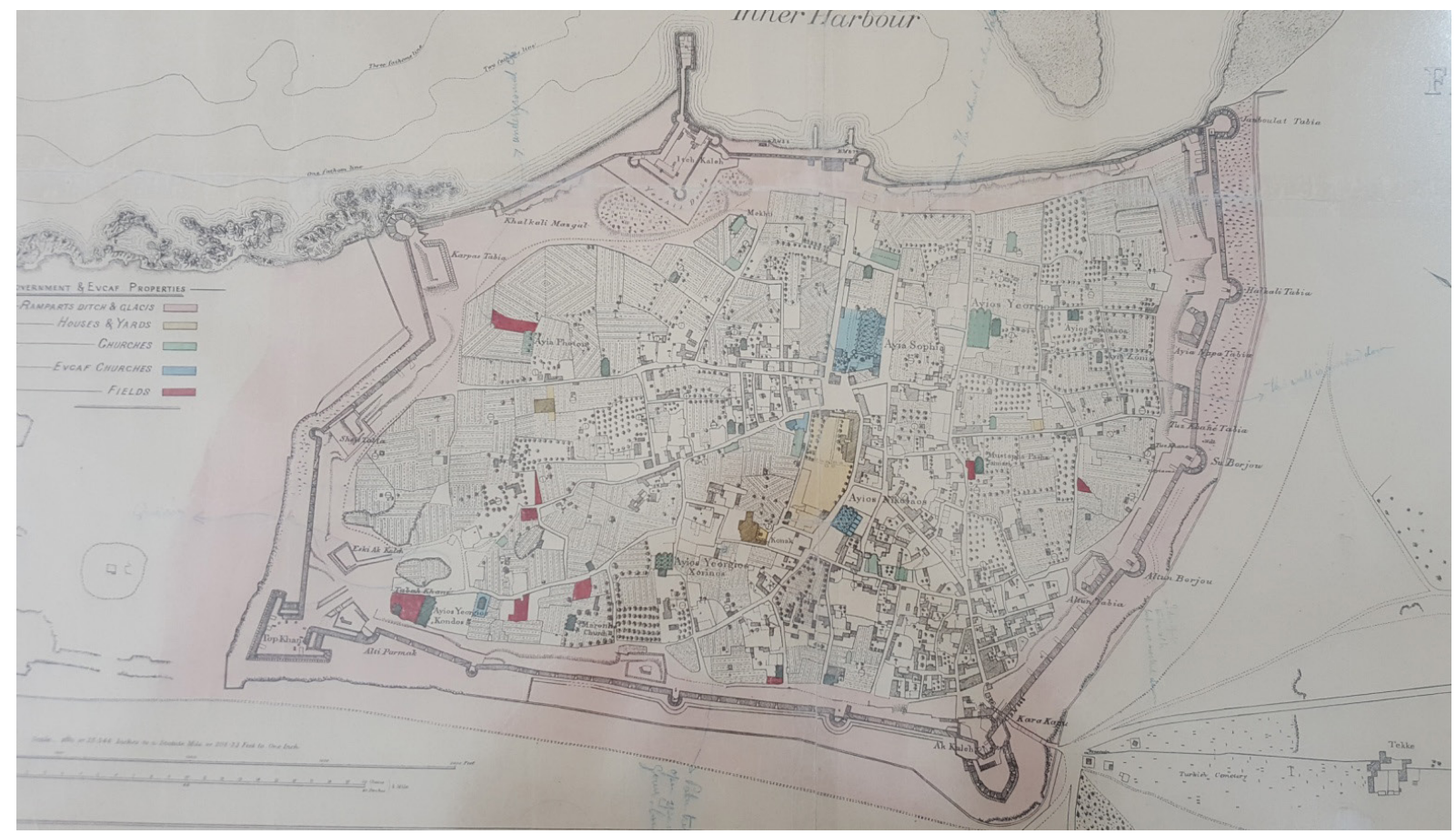

Figure 3. Lieutenant S.C.N. Grant, R.E. Director of Survey, "Map of Famagusta", 1:2500, ca. 1903 (Grant 1903). Source: The National Archives of Turkish Republic of Northern Cyprus

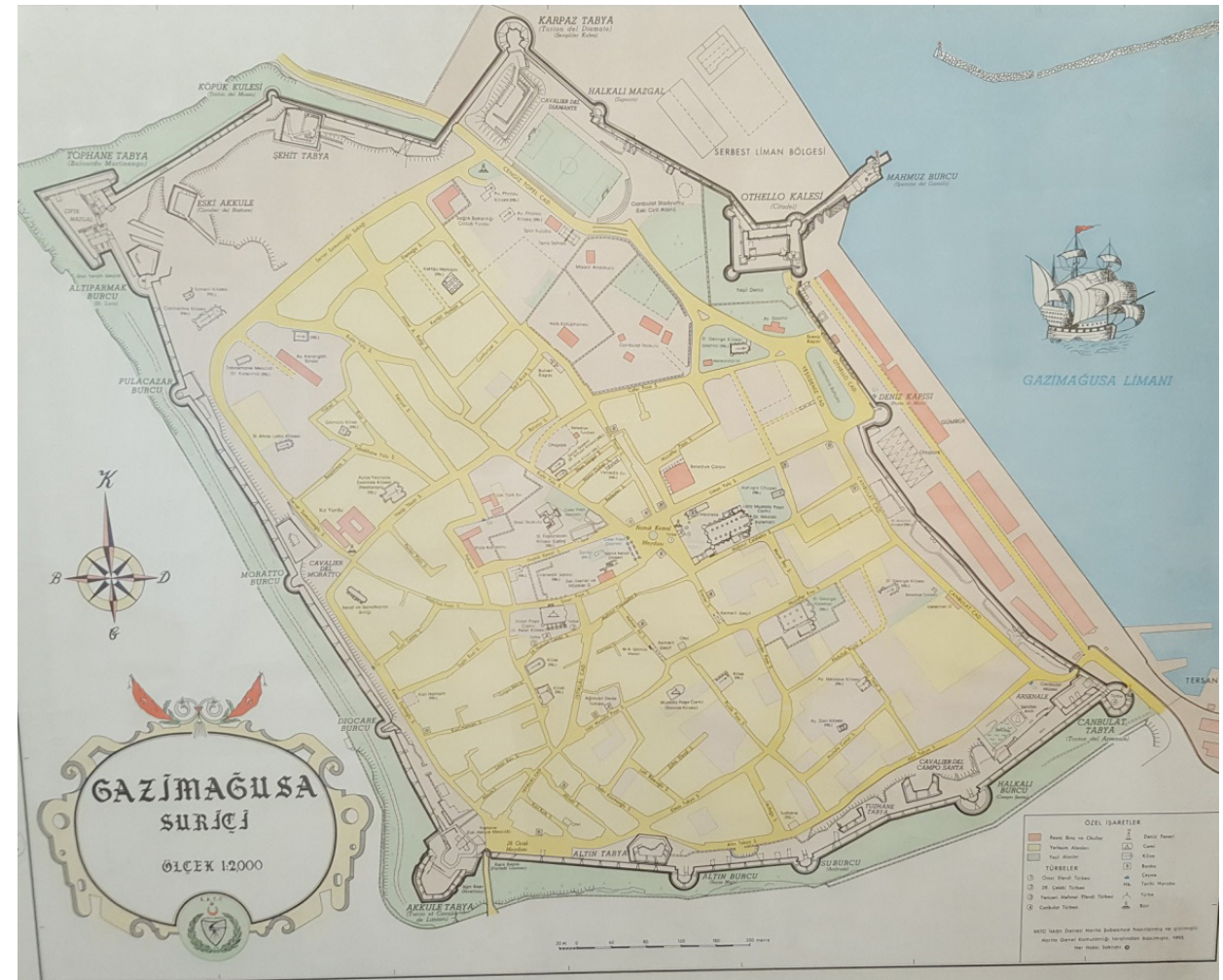

Figure 4. Housing and Rehabilitation Department, TRNC, "GaziMagusa Suriçi” (Famagusta Walled City), 1:2000, 1995. Source: The National Archives of Turkish Republic of Northern Cyprus. 
Maras region (Varosha) was closed off to habitation and as a result, the residential area and developments increased within the walled city but were limited (Önal, et al. 1999). In addition, due to the economic problems caused by the war and the necessity for quick solutions for residents and rural migrants, many featureless structures were built within the city walls. Due to the rapidly increasing population within the walls (Uluca 2006), the area in the north of the city filled with private buildings unsuited to the city's historic character. A stadium filled the empty area near the Othello castle. A new gate was opened on the East side of the city around 1965. After 1983, the population decreased as the walled city became unappealing to live in. In 1990, a project to renovate the inner city ended unsuccessfully causing a loss of commercial interest. As few historical buildings were renovated, the city never reached its potential as a historical tourist city nor a commercial one. When the new university was established outside the walled city, a new phase of construction started around it, which forms the new and current structure of the city outside the walls.

The GaziMagusa Surici map from 1995 shows the major historical buildings that are still standing (Fig. 4). St. Nicholas and other major churches are labelled with both their old and new names. Some major historical monuments were still standing in the walled city, but many are in ruins. St. George of the Greeks and St. George of the Latins are two examples. Today both churches are in ruins with few walls standing. St. George Greek's walls are particularly incomplete. The churches used in later centuries, such as St. Nicholas, Saints. Peter and Paul, St. Antonio are still standing. On the map, these structures are shown with their outlines and the converted ones are emphasized. These various significant historical buildings in this historically rich city are in danger and face destruction. On the map, we can clearly see what is left of the Venetian Palace and its ruined walls, which were used as a car park for a period.

Yellow is used to show areas of increasing population and green to show empty areas like parks stadiums and the moat. New buildings such as schools, the stadium, the library and administration buildings are shown in red. The new gate between Torion del Mezzo bastion (Köpük Kule) and Torion del Diamate bastian (Karpaz Tabya), which was opened in 1965, can also be seen. According to the Project, in the 1990's some of the roads were closed to the traffic e.g. İstiklal and Sinan Paşa streets. However, the differences on the street plan are not reflected. The map is not detailed enough to show us the irregular settlement and developments that the city underwent in recent decades. Modern maps became more detailed. Although, they could not fully represent the city or its historical and social background, they helped to administrate the city and surroundings.

\section{Conclusion}

The $16^{\text {th }}$ century siege maps of Famagusta focused on the siege and its historical context as the last location of the Ottoman conquest of Cyprus, making it a centre of interest. The map by Gibellino captures most details about the city with the addition of a reference table to show and identify the important buildings of the city and its fortifications. These structures are depicted on the maps representing the city over the next centuries. During the Ottoman Era, the city lost its importance as the trade centre of the island, which was reflected in terms of basic identification features in the various representations of the city that followed. Dapper's map shows the inner plan of the city, but not all of the significant buildings are indicated. The current situation of the city described in written accounts was illustrated with the buildings in ruins. Even though it shows this situation, it does not give an accurate and reliable image of the changes that occurred during the Ottoman Famagusta. Later on, the British government tried to return the port to its glory days, while the renovations within the city walls became a secondary consideration. The British map shows the city's structure, identity and even the plan of some of the public buildings, however, it focuses on the Christian monuments and shows selected public buildings and has major errors in labelling them, hence, the map does not create an accurate image of the city. Today's modern maps indicate several layers of the historical city. Even though they depict the important historical structures of the city and new public buildings, they still lack information about the changes that the city underwent and aren't detailed enough to show the rising irregular settlements within the walled city.

Famagusta is one of the wonders of Cyprus that has an inspiring past with historical structures in sight at every turn and provides a wondrous spectacle of the Mediterranean Sea beyond its harbour. As maps are visual sources to a city's turbulent history, studying maps depicting the city may enrich and expand our knowledge of this geographical space. The cartographic representation of Famagusta and mix of identities does not necessarily reflect the city's built environment or its constantly changing history and the maps can only partially capture the city's charm and its identity. Cartographers prioritise the historical structures and fortifications from the medieval era as the main features. Besides the descriptive features of the representations, these images of the city were not always able to reflect its social or cultural context. Additionally, most of the maps also omit changes in the city's urban fabric. This lack of information and interest, which leads to gaps in the maps and creates discontinuity in depictions of the developments and at times, brings the examination of the past to a halt. The representations are various and changeable according to their era and context in, and the purpose of the structures was the determining feature of the images of the city. The changing urban fabric of the city may partially be followed on the maps. The maps give us sufficient information to follow the majority of the history of Famagusta and highlight the historical importance of the city.

\section{References}

Arkan, M 2017, The urban cartography of Cyprus: Between the 16th and 20th centuries, Ph.D thesis Eötvös Lorand University.

Cobham, CD 1908, Excerpta Cypria: Materials for a history of Cyprus: with an appendix on the bibliography of Cyprus, Cambridge University Press, Cambridge.

Dapper, O 1688, "Famagusta", in Naukeurige Beschryving der Eilanden in de Archipel der Middelantsche Zee, en ontrent dezelve, gelegen: Waer onder de voornaemste Cyprus, Rhodes, Kandien, Samos, Scio, Negroponte, Lemnos, Paros, Delos, Patmos, en andere, in groten getale... (Detailed Description of the Islands in and around the Archipelago of the Mediterranean Sea: Major ones are Cyprus, Rhodes, Kandien, Samos, Scio, Negroponte, Lemnos, Paros, Delos, Patmos, and many other locations...), Amsterdam, 1688, Hellenic Library - Alexander S. Onassis Public Benefit Foundation, Aikaterini Laskaridis Foundation.

Edbury, PW 1999, Kingdoms of the Crusades: From Jerusalem to Cyprus. Ashgate, Aldershot, Hampshire, Great Britain.

Enlart, C 1987, Gothic art and the renaissance in Cyprus, trans. D Hunt, Trigraph, London.

Gibellino, S 1571, "Al motto Mag. Sig. ...Negrobon... ritratto della celebre citta di Famagosta" (To his Excellency the 
Honourable Captain Negrebon... portrait of the famous city of Famagusta), Brescia, 1571, Bibliothéque Nationale, Departement des Imprimés, Paris.

Grant, RE 1903, Director of Survey, Map of Famagusta, 1:2500, ca. 1903, The National Archives of Turkish Republic of Northern Cyprus

Gunnis, R 1947, Historic Cyprus: A guide to its town and villages, monasteries and castles, $2^{\text {nd }}$ edn, Methuen \& Co. Ltd, London.

Harley, JB 2001, The new nature of maps, The Johns Hopkins University Press, Baltimore.

Hill, G 1952, A history of Cyprus, Cambridge University Press, Cambridge.

Jacoby, D 1989, Studies on the crusader states and Venetian expansion, Variorum Reprints, Northampton.

Jeffery, GFSA 1918, A description of the historic monuments of Cyprus, William James Archer, Government Printer, At the Government Printing Office, Nicosia.

Luke, H 1969, Cyprus under the Turks: 1571-1878, $2^{\text {nd }}$ edn, C. Hurst \& Company, London.

Marangou, AG 2002, The harbours and ports of Cyprus, Laiki Group Cultural Centre, Nicosia.

Navari, L (ed.) 2003, Maps of Cyprus: from the collections of the Bank of Cyprus Cultural Foundation, Bank of Cyprus Cultural Foundation, Nicosia.

Orr, CWJ 1918, Cyprus under British Rule, Zeno publishers, London.

Önal, Ş, Dağlı, U \& Doratı, N 1999 'The urban problems of Gazimagusa (Famagusta) and proposals for the future' Cities, vol. 16, no. 5, pp. 333-351.

Richter, H. A 2011, Çağdaş Kıbrıs'ın Kısa Tarihi 1878-2009, [A Concise History of Modern Cyprus, 1878-2009] trans. A Çakıroğlu, Galeri Kültür Yayınları, Nicosia.

Stavrinides, Z 1999, The Cyprus Conflict, Cyprus Research \& Publishing Centre, Nicosia.

Stylianou, A \& Stylianou, JA 1980, The history of the cartography of Cyprus, Cyprus Research Centre, Nicosia.

Uluca, E 2006, Gazimağusa kaleiçi'nin Tarihsel Süreç içindeki Kentsel Gelişimi ve Değişimi. [The historical process of urban development and transformation of the city of Famagusta.] Ph.D thesis İstanbul Teknik University.

Uluca, E \& Akın, N 2008 'Gazimağusa Limanı: 13. Yüzyıldan 20. yüzyıla bir Akdeniz limanının gelişimi' [Famagusta harbour: the development of a Mediterranean port from the 13th to the 20th century.] ITÜ dergisi, mimarlık, planlama,tasarım, vol.7, no.1, pp. $62-73$ 